\title{
PECULIARITIES OF THE DEVELOPMENT OF SPECIAL STRENGTH PREPARATION DURING THE WINTER MACROCYCLE FOR THE 800 m EVENT
}

\author{
H.T. Stoyanov, info@akademik-bg.com, ORCID: 0000-0001-6129-8056 \\ Athletic club AKADEMIK, Sofia, Bulgaria
}

\begin{abstract}
Aim. To study the dynamics of the development of strength and speed-strength characteristics in men's $800 \mathrm{~m}$ training during the winter macrocycle of running preparation. Material and methods. Four middle-distance athletes were included in the study. Seven indicators characterizing the strength- and speed-strength development were assessed during seven mesocycles of winter preparation. Results. The total strength reached its maximum volume in the first and second mesocycles. We tried to achieve a balance between the development of strength and endurance. Using special running exercises and short alternate leg bounds in the second and sixth mesocycles proved to have a forming input on special running preparation. The development of strength endurance takes place in the first three mesocycles. Conclusion. The strength and speed-strength training of $800 \mathrm{~m}$ runners has great importance for achieving high sports results. The effectiveness of the training process depends to a great extent on the structural distribution of strength preparation among the different mesocycles.
\end{abstract}

Keywords: middle distance running, strength, speed, speed-strength training.

\section{Introduction}

Special strength preparation depends on the choice of tools and methods, and how they are distributed across the micro-, meso-, and macrocycles of the training process. This choice should concord with the athlete's level, and with the priorities for developing different qualities depending on the running distance. It is of crucial importance to find a proper combination of strength load elements distributed in each mesocycle. Such a combination could help most efficiently the running preparation, at the same time, taking into account the specific structure of movements typical for $800 \mathrm{~m}$ and $1500 \mathrm{~m}$.

In this respect, many authors $[5,6,10,13$, $17,21]$ classified the strength and speed-strength tools by relating them to their appearance in running preparation. Particularly, some authors $[7,9,15,18]$ studied the relationship between the strength and speed-strength tools and their effect on the development of specific qualities by connecting them to special speed endurance and anaerobic power. The authors propose the tests for classifying the speed-strength capabilities of the athletes.

Hoff et al. [8] and Spurrs et al. [16] studied the effect of plyometric exercises on the economy of movement in long-distance athletes.

The leading principle in choosing the tools for the development of strength depending on their specifics of appearance according to $[11,19$,
20] is the one of dynamic strength correspondence i.e., strength preparation tools should be adequate to the working regime of the motor apparatus, and they should contribute to the apparatus' quality improvement.

It is often postulated $[1,2]$ that each running event has its strength characteristics, shaping the final result. With increasing the distance, especially in the longer sprint events, strength endurance becomes progressively more important $[3,20,21]$.

In each event, the different motor qualities are expressed at a different level. The final result in middle-distance running is determined by the effect of each of these qualities and by their cumulative effect.

The importance of strength preparation is underestimated both in the sports practice and in research. Running movement economy, anaerobic threshold, and its relationship with the accumulation of plasma lactate have received considerably more attention $[4,14]$. The effect of specific running preparation on the result is widely studied [12], while the positive effect of the strength and speed-strength load was underestimated. Planning of running preparation with the skillful combination of strength and speed-strength load requires consistency and prioritization in their development.

The objective of the present study was to assess the dynamics of the development of strength 
and speed-strength indicators in $800 \mathrm{~m}$ training during the winter macrocycle of running preparation.

The following tasks were set for achieving this general objective:

1. Studying the dynamics of the development of total strength during each mesocycle of the winter macrocycle.

2. Analyzing the dynamics of the development of speed-strength including training with weights; speed-strength in metric units; and plyometric kind of exercises during each mesocycle of the winter macrocycle.

3. Assessing the dynamics of the development of maximum strength during each mesocycle of the winter macrocycle.

4. Analyzing the dynamics of the development of strength endurance developed by training with weights and strength endurance in metric units during each mesocycle in the winter macrocycle.

\section{Material and methods}

The study included four highly ranked athletes in men's $800 \mathrm{~m}$ and $1500 \mathrm{~m}$ events who have been in top 3 in the respective event in Bulgaria in the last 20 years and have been national champions at the top of national ranking multiple times. The athletes were not subjected to heavy training load - they were full-time students and trained only once a day. The qualification characteristics of the athletes are nearly identical, and they are presented in the personal diaries of the athletes (Table 1).

The study focuses on the dynamics of the development of strength- and speed-strength training load during seven mesocycles of the winter macrocycle, which is the most important for the performance of the athletes throughout the year. It usually starts in the mid of September and finishes at the beginning of March. The duration of mesocycles varies according to their phases as follows: in the preparation period (mesocycles from I to V) is 3 weeks, in the pre-season (VI) and the season (VII) is 4 weeks. The total duration of the winter macrocycle is 23 weeks, which is not different from the one practiced in Bulgaria and abroad.

The special types of strength affecting to a greater extent the development of strength potential in athletes are reviewed depending on the energy supply. Their development is followed during the different mesocycles, and they are subdivided into two main groups:

I. Strength training work is done by using weights and simulators and is structured in four main directions:

1. Development of a general strength where the duration of the workout is more than one minute and helps the development of the oxidation processes (cyclic training sessions are used with low weight and many repetitions) (Table 2, pos. 1);

2. Development of speed-strength with a predominance of anaerobic lactate energy mechanism (the focus is on the speed of session with a weight about $20-30 \%$ of the maximum abilities, and with duration up to $15 \mathrm{sec}$.) (Table 2, pos. 3);

3. Work for strength endurance, directed to the improvement of the anaerobic lactate mechanism (developed with weighs up to $50 \%$ of the maximum ability, and is performed until exhaustion) (Table 2, pos. 6);

4. Development of the maximum strength with anaerobe supply (pyramidal method with reaching of the maximum is applied) (Table 2, pos. 4).

II. Work for the development of the strength without weights, including different jumping exercises:

1. Fundamental workouts, i.e., leading to the strengthening of the bone-jointing apparatus, as a base for sustaining larger volume and intensity running or strength work. The processes here take place in anaerobe to aerobe conditions (this

Qualification characteristics of the athletes

Table 1

\begin{tabular}{|l|c|c|c|c|c|c|c|}
\hline \multirow{2}{*}{$\begin{array}{c}\text { Researched } \\
\text { group }\end{array}$} & \multicolumn{7}{|c|}{ Indices } \\
\cline { 2 - 8 } & Height (cm) & \multirow{2}{*}{$\begin{array}{c}\text { Weight } \\
(\mathrm{Kg})\end{array}$} & \multirow{2}{*}{$\begin{array}{c}\text { Age } \\
\text { (years) }\end{array}$} & $400 \mathrm{~m}$ & $800 \mathrm{~m}$ & $1500 \mathrm{~m}$ & Experience \\
\cline { 5 - 9 } & & 70 & 25 & 48.66 & 1.48 .89 & 3.58 .20 & 8 \\
\hline Athlete 1 & 176 & 67 & 26 & 49.15 & 1.50 .56 & 3.59 .00 & 7 \\
\hline Athlete 2 & 178 & 65 & 22 & 49.17 & 1.50 .57 & 3.59 .56 & 6 \\
\hline Athlete 3 & 178 & 66 & 25 & 51.35 & 1.52 .10 & 3.58 .13 & 6 \\
\hline Athlete 4 & 176 & 67 & 24.5 & 49.58 & 1.50 .53 & 3.58 .72 & 6.75 \\
\hline Mean value & 177 & 67 & & & & & Result \\
\hline
\end{tabular}


Dynamics of the development of strength and speed strength training indicators by mesocycle during the winter macrocycle

\begin{tabular}{|c|c|c|c|c|c|c|c|c|}
\hline \multirow{2}{*}{ No } & \multirow{2}{*}{ Mesocycle } & \multicolumn{5}{|c|}{ Preparation period } & \multirow{2}{*}{$\frac{\text { Pre-season }}{\text { VI }}$} & \multirow{2}{*}{$\frac{\text { Season }}{\text { VII }}$} \\
\hline & & $\mathrm{I}$ & II & III & IV & $\mathrm{V}$ & & \\
\hline 1 & Total strength $(\mathrm{t})$ & 7.2 & 12.6 & 10.2 & 9.3 & 8.4 & 7.5 & 6.6 \\
\hline 2 & Speed strength $(\mathrm{km})$ & 2.4 & 3.3 & 2.25 & 2.4 & 2.55 & 4.2 & 1.8 \\
\hline 3 & Speed strength (t) & 12 & 12.3 & 24.6 & 22.2 & 21.3 & 19.8 & 18.9 \\
\hline 4 & Maximum strength $(\mathrm{t})$ & & 8.1 & 17.7 & 21 & 18.6 & 15.9 & 8.1 \\
\hline 5 & Speed strength (jumps) & 1680 & 1920 & 1860 & 1780 & 1750 & 1590 & 1440 \\
\hline 6 & Strength endurance(t) & 0 & 10.2 & 21.3 & 19.2 & 16.5 & 12.3 & 6.3 \\
\hline 7 & Strength endurance $(\mathrm{km})$ & 6.9 & 7.5 & 6 & 5.7 & 4.5 & 4.2 & 2.7 \\
\hline
\end{tabular}

workout is not included in the training indicators in Table 2 because of no quantitative indicators).

2. Strength and speed-strength training work in metric units. It includes the volume of the specialized exercises - short leg bounds and jumps (Table 2, pos. 2 and 5).

3. Exercises for development of the strength endurance (special running exercises, leg bounding up to $100 \mathrm{~m}$, uphill running, running in sand, truck tire running) (Table 2, pos. 7).

In Table 2 are presented the training parameters of the development of strength- and speedstrength in each mesocycle.

\section{Results and discussion}

Five of the studied strength and speedstrength characteristics are used in the structure of the first mesocycle. Total strength development is naturally included in the first mesocycle. Exercises with light weights and high repetition number are executed for all muscle groups. The total volume is $7.2 \mathrm{t}$ (Fig. 1). Three types of speed-strength training work are included in the first mesocycle. The first type is the volume of speed development by special running exercises and short alternate leg bounds, which help speed development with a volume of $2.4 \mathrm{~km}$ (Fig. 2). Jumps improve the second type of speed strength, and although their volume is low - 1680 jumps, they build up the quality. The third type of tool for speed-strength development in the first mesocycle is training work by plyometric exercises with a volume of $12 \mathrm{t}$.

Another strength characteristic taking part in the development of the strength capacity of $800 \mathrm{~m}$ runners is strength endurance. There are two types of exercises for the development of strength endurance - special running exercises (against slope with a sled) and alternate leg bounds up to $100 \mathrm{~m}$. The volume of the training load is $6.9 \mathrm{~km}$.

The analysis of the factorial structure of me- socycles and the training loads included, as well as their effect on the sports results in $400 \mathrm{~m}$, was established as a relationship between the work volume for speed strength through special running exercises and short alternate leg bounding, speed, speed endurance and the result [18].

During the second mesocycle, all seven indicators of the development of strength and speed-strength qualities of runners are used in the training load. The total strength volume increased by $43 \%$ as a result of the increased number of exercises. The speed-strength modeled by special running exercises and short alternate leg bounding is also with increased volume, due to increasing the number of repetitions. Two training sessions are planned for the second mesocycle, and the total volume is raised by $27 \%$.

The volume of speed-strength improved with the help of jumps in the second mesocycle reaches its maximum value of 1920 repetitions. Plyometric exercises and jumping with weights which take part in the development of speed-strength $(\mathrm{t})$ keep their volume values, but they are executed more explosively, helping the development of explosive strength. An important remark is that with the volume of $8.1 \mathrm{t}$ during the second mesocycle maximum strength takes part in strength preparation. The fifth type of strength loads which complete weight work are exercises for developing strength endurance, which are also included at the beginning of the second mesocycle. They are executed in high repetitions (maximum repetitions) with light weights and the total volume of $10.2 \mathrm{t}$.

The total volume of special running exercises (against a slope, with a sled) and alternate leg bounds up to $100 \mathrm{~m}$ for developing strength endurance have a minimal increase of $8 \%$ as the exercises distance length is greater.

During the third mesocycle strength training load changes its importance, which is expressed by decreasing by $19 \%$ the volume of total 


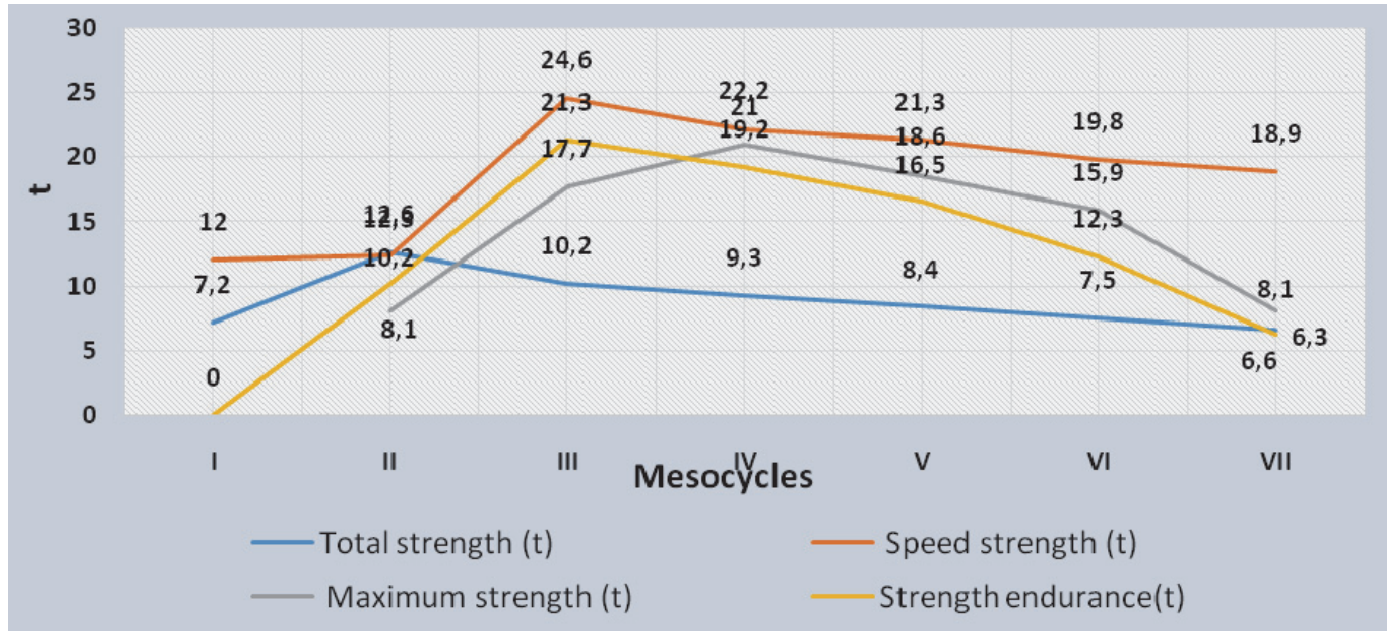

Fig. 1. The dynamics of the development of total strength, speed strength $(t)$, maximum strength, and strength endurance $(t)$ during each mesocycle

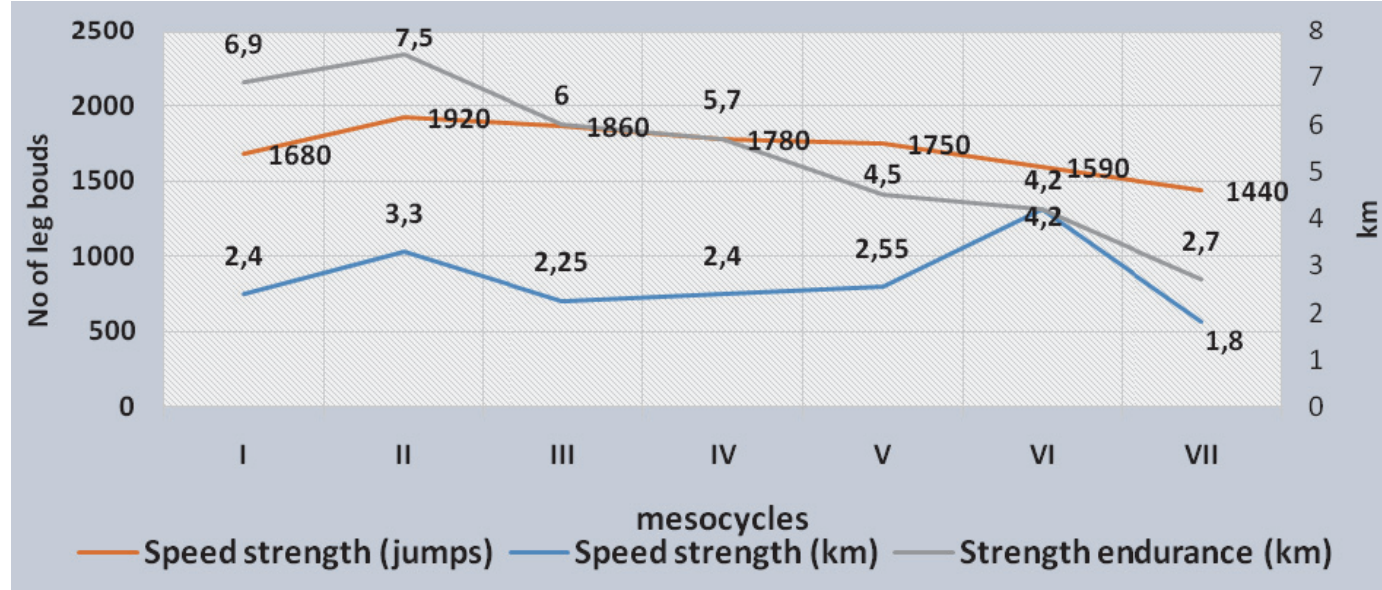

Fig. 2. Dynamics of the development of the training indicators $(\mathbf{k m})$ during seven mesocycles

strength work. This type of training work is used now for maintaining the sport form.

In direct relation to the statement above, speed-strength exercises with weights increase by $100 \%$ as there are now two training sessions in the weekly microcycle. The development of this type of strength helps to improve the neuromuscular innervation. Maximum strength volume, too, is increased by $119 \%$. During the third mesocycle, this increase in volume is a result of using more exercises for developing this quality (squats with maximum weight, half squats with maximum weight). The total volume of speedstrength developed by special running exercises and short alternate leg bounds is lowered by $32 \%$ as a consequence of the removal from the training process of short alternate leg bounds. Training work for speed strength improved with the help of jumps is lowered by $3 \%$, but the nature of jump exercises performance is altered. The total volume of strength endurance development by special running exercises (against a slope, with a sled) and alternate leg bound up to $100 \mathrm{~m}$ lower by $20 \%$ as a result of the restructuring the training tools used.

In the fourth mesocycle, the use of all fundamental training means for developing the athlete's strength qualities continues. After a decrease of $19 \%$ in the third mesocycle, now it decreases further with another $8.8 \%$.

It is worth to point our attention to the variability of the volume of speed-strength by special running exercises and short alternate leg bounds after a considerable decrease of $32 \%$ in the third mesocycle. Now, in the fourth mesocycle, there is a rise of $6 \%$ as a result of additional increases in the training volume of frequency running. The volume of training work for the development of maximum strength in this mesocycle reaches its maximum values after an increase of $13 \%$. 


\section{Спортивная тренировка}

During the fourth mesocycle, exercises with weights for developing speed strength and strength endurance fall by almost $10 \%$. There is also a small decrease of $5 \%$ of the total volume of strength endurance.

The reorganization of the running preparation in the fifth mesocycle with focusing on the development of creatine phosphate and the anaerobe-alactic regime of energy supply leads to a new distribution of speed and strength training loads.

The total volume of speed-strength by special running exercises and short alternate leg bounds increases by another $6 \%$. The work for speed strength modeled using jumps and alternate leg bounding is slightly lowered. The volume of speed-strength developed using weights slightly decreases by $4 \%$. The exercises are performed with higher intensity. The volume indicators of maximum strength go down by almost $12 \%$ as this type of training takes place only once in a weekly microcycle. Similar decrease by $14 \%$ takes place concerning the exercises with weights for the development of strength endurance. The most significant decrease of $21 \%$ happens in the volume of strength endurance work by special running exercises (against a slope, with a sled) and alternate leg bounds up to $100 \mathrm{~m}$.

During the sixth, pre-season mesocycle, the middle-distance runners' attention focuses on the development of special running preparation and achieving a satisfactory form. While during the previous mesocycle the volume of speedstrength $(\mathrm{km})$ went up by $6 \%$, in the sixth mesocycle, it goes up to as much as $39 \%$. Using a high number of training means for developing speedstrength (jump repetition) with a minimal decrease of only $9 \%$. The volume of speed-strength developed with weights is lowered by only $7 \%$. Prioritized training work for speed and explosive strength during the sixth mesocycle is connected to maintaining high muscle tone. High muscle tone helps special running preparation. There is a little change of near $7 \%$ in the volume of strength endurance using special running exercises like alternate leg bound up to $100 \mathrm{~m}$ and running with car tire against the slope. The maximum strength in the sixth mesocycle has a lower volume of $15 \%$, and it has a maintenance function. The most considerable decrease of $25.5 \%$ is observed in strength endurance by weights. Maintaining high volume values of this type of strength would negatively affect running preparation.

The changed character and direction of the seventh mesocycle underlines the importance of strength and speed-strength characteristics and suggest that they will play an important role in achieving sports time. Even though the volume of speed-strength modeled by short alternate leg bounding is lowered by $57 \%$, the exercises are performed with maximum intensity. There is a minimal decrease of $4.5 \%$ of speed-strength ( $t$ ), but this tool still keeps enough high level of load to provoke high levels of muscle tone in the course of improving the special running preparation.

Strength endurance ( $t$ ) by exercises with weights also has lowered volume by $49 \%$ as the exercises are performed for the time recorded by stopwatch. The same concerns the strength endurance $(\mathrm{km})$ by alternate leg bounds up to $100 \mathrm{~m}$. The total volume has considerably fallen by near $36 \%$. During the microcycles which are in a race week, the alternate leg bounds are displaced by running with the sled.

\section{Conclusions and recommendations}

The special types of strength with weights exert the most influence on the building up of the middle-distance runners' strength potential are inspected in each mesocycle. The priority and variability of these types of strength are in accordance with running preparation energetics during the analyzed macrocycle of preparation. They are essential for the development of special running work through individual mesocycles during the study period.

1. The analysis of dynamics in the development of the volume indicators of the total strength revealed that during the first two mesocycles it reaches its maximum volume values, thus helping the development of the general capacity of the athletes, while at later stages this type of training work plays a maintaining role and decreases continuously until the end of the macrocycle.

2. Training work for developing maximum strength starts with minimal volume in the second mesocycle, reaches its maximum value during the fourth mesocycle and then decreases continuously until the end of the macrocycle. The study revealed that the dynamics of development and volume values of the maximum strength affect in the best way both re-structuring of the training and building of the other types of strength in the different mesocycles.

3. The dynamics of the development of speed-strength in metric units shows that in the second and sixth mesocycles speed strength's 
volume values are the highest. This indicates that the effect of using special running exercises and short alternate leg bounds in these mesocycles shows their forming input on special running preparation.

4. Speed strength with weights starts with nearly identical indicators during the first and the second mesocycles. After reaching the maximum volume value in the third mesocycle and then it slowly decreases evenly with less than $10 \%$ in the next mesocycles.

5. The analysis of the development of speedstrength by plyometric exercises shows that training work starts already in the first mesocycle. Speed strength volume maximum values are reached in the second mesocycle, and after that, these values decrease by $3 \%$ to $9 \%$ until the end of the macrocycle, but they are in balance with the rest of speed-strength indicators.

6. The study of strength endurance in tones shows that its development starts in the second mesocycle, reaches its highest training volume during the third mesocycle, remain almost the same in the fourth mesocycle and starts to decrease between the fourth and fifth mesocycle by $14 \%$, between the fifth and the sixth mesocycles by $25 \%$ and $49 \%$ decrease is between the last two mesocycles.

7. The analysis of the development of the volume of strength endurance $(\mathrm{km})$ shows that it starts already in the first mesocycle and reaches its highest indices in the second mesocycle. During the next mesocycles strength endurance decreases irregularly, depending on the priority of running preparation, and the largest decrease is marked between the sixth mesocycle and seventh mesocycle of $36 \%$.

\section{References}

1. Antonov N. The Special Strength Training for Sprinters. Trenyorska Misal, 1984, no. 4.

2. Bachvarov M. Running of 100 and $200 \mathrm{~m}$. S., Medicina \& Fizkultura, 1976.

3. Bonov P., Bonova I., Shalamanova D. Methodology of the Contemporary Training for Middle- and Long Distance Running. Sofia, 2013. NSA Press.

4. Bonova I., Shalamanova D. Development of the Running Economy in 13-19-Year Old Middle Distance Runners by Means of a Specific Training Program in the Preparation Period. Leka Atletika \& Nauka, 2017, pp. 33-37.

5. Dimitrov D. Possibilities for Improvement of the Age Structure and Contents of the Training Process in Running with Maximum and Subma- ximum Intensities. D. Sc. thesis, 2002, National Sports Academy, Sofia.

6. Gadev M., Milenski M. Classification of Strength- and Speed-Strength Tools for Development of the Maximum Speed in the Sprint. Sport i Nauka, 1997, no. 5-6, pp. 38-40.

7. Gadev M. Study on the Relationships Between the Special Endurance and the Speed and Speed-Strength Moving Abilities in the Football for Children and Juniors. Sport i Nauka, 2013, no. 5, pp. 36-41.

8. Hoff J., Helgerud J., Wislof U. Endurance Training Into the Next Millennium: Muscular Strength Training on Aerobic Endurance Performance. American Journal of Medicine in Sports, 2002, no. 4, pp. 58-67.

9. Karabiberov Y., Lazarov G. A Test for Evaluation of the Strength Endurance and Predicting the Sport Result in $800 \mathrm{~m}$. Vaprosi na Fizicheskata Kultura, 1988, no. 6, pp. 16-18.

10. Karabiberov Y., Bachvarov M. Correlation Structure of the Speed-and-Strength Preparation of the Middle Distance Runners. Vaprosi na Fizicheskata Kultura, 1987, no. 55, pp. 9-13.

11. Kuznetsov V.V. Peculiarities in the Expression of Relationship Between the Parameters of Strength and Speed in Cyclic Locomotions. Teoriya i Praktika Fizicheskoy Kul'tury, 1985, no. 8 .

12. Lazarov I. Research the Effects of Specific Running Preparedness on Sports Result in Athletes Running on $800 \mathrm{~m}$ and $1500 \mathrm{~m}$ meters. Leka Atletika \& Nauka, 2016, pp. 57-61.

13. Levchenko A. Special Strength Preparation of the Sprinters. Legkaya Atletika, 1982, no. 4.

14. Ofner M., Wonisch M., Frei M., Tschakert G., Domej W., Kropfl J., Hofmann P. Influence of Acute Normobaric Hypoxia on Physiological Variables and Lactate Turn Point Determination in Trained Men. Journal of Sports Science and Medicine, 2014, vol. 13, pp. 774-781.

15. Peev P., Gadev M., Hristov O., Petrova B., Mihaylov I. Relationship Between the Indicators Characterizing the Anaerobic Power and Variations of Jumps in Vertical Plane in 14-Year Old Footballers. Leka Atletika \& Nauka, 2017, no. 1 (17), pp. 25-32.

16. Spurrs R.W., Murphy A.J., Watsford M.L. The Effect of Plyometric Training on Distance Running Performance. European Journal of Applied Physiology, 2003, vol. 89, no. 1, pp. 1-7. DOI: 10.1007/s00421-002-0741-y

17. Stoyanov H. Methods for Preparation and Training Models in 200 and $400 \mathrm{~m}$. Sofia, 2013. NSA Press. 


\title{
Спортивная тренировка
}

18. Stoyanov H. Theoretical and Methodologic Aspects in the Development of the Special Running Qualities in 200 and $400 \mathrm{~m}$. Sofia, 2016, Tip-Top Press, $111 \mathrm{p}$.

19. Verhoshanskiy Yu. A New Training System in the Cyclic Sports. Sport \& Nauka, 1994, no. 4.
20. Verhoshanskiy Yu. Physiological Basis of the Methodological Principles in Endurance Running. Moscow, Sovetskiy Sport Publ., 2017. $80 \mathrm{p}$.

21. Zatsiorsky V.M. The Physical Qualities of the Sportsman. M., Fizkultura i Sport, 1966. $200 \mathrm{p}$.

Received 13 May 2019

УдК 796.422.12

DOI: $10.14529 / h s m 19 s 115$

\section{ОСОБЕННОСТИ РАЗВИТИЯ СПЕЦИАЛЬНОЙ СИЛЫ В ЗИМНЕМ МАКРОЦИКЛЕ ПОДГОТОВКИ К БЕГУ НА 800 МЕТРОВ}

\author{
X.T. Стоянов \\ Спортивный клуб «Академик», г. София, Болгария
}

Цель. Цель данного исследования - изучить динамику развития силовых и скоростносиловых качеств в зимнем макроцикле подготовки к бегу на 800 м для мужчин. Материалы и методы. 4 бегуна на средние дистанции участвовали в исследовании. На протяжении семи мезоциклов зимней подготовки авторами проводилась оценка семи показателей, характеризующих силовое и скоростно-силовое развитие. Результаты. Общая сила достигает своего максимального объема в первом и втором мезоциклах. Авторы предприняли попытку достигнуть баланса между развитием силы и выносливости. Использование специальных беговых и прыжковых упражнений во втором и шестом мезоциклах продемонстрировало формирующий эффект в отношении специальной беговой подготовки. Развитие силовой выносливости происходит в первых трех мезоциклах. Заключение. Силовые и скоростно-силовые тренировки бегунов на 800 метров имеют важное значение для достижения высоких спортивных результатов. Эффективность тренировки в значительной степени зависит от структурного распределения силовой подготовки между различными мезоциклами.

Keywords: бег на средние дистанции, сила, скорость, скоростно-силовые тренировки.

Христо Стоянов, Ph.D., главный тренер, спортивный клуб «Академик». Бульвар Климента Oxридского, 9, 1756, г. София, Болгария. E-mail: info@akademik-bg.com, ORCID: 0000-0001-6129-8056.

Поступила в редакцию 13 мая 2019 г.

\section{ОБРАЗЕЦ ЦИТИРОВАНИЯ}

Stoyanov, H.T. Peculiarities of the Development of Special Strength Preparation During the Winter Macrocycle for the $800 \mathrm{~m}$ Event / Н.T. Stoyanov // Человек. Спорт. Медицина. - 2019. - Т. 19, № S1. - С. 114-120. DOI: $10.14529 / \mathrm{hsm} 19 \mathrm{~s} 115$

\section{FOR CITATION}

Stoyanov H.T. Peculiarities of the Development of Special Strength Preparation During the Winter Macrocycle for the $800 \mathrm{~m}$ Event. Human. Sport. Medicine, 2019, vol. 19 , no. S1, pp. 114-120. DOI: 10.14529/hsm19s115 